proposals for the solar maximum at its meeting in October. But here, again, the time has probably come to start thinking of institutions, not just of programmes. In particular, there is a great need for some means of keeping the ball rolling frem one sunspot maximum to the next. It is also, of course, important that the management should get itself into a position in which it can tactfully discriminate between efficient research proposals and those likely only to repeat earlier investigations-a need which, to be fair, seemed to have been fully recognized in London last week. On these counts as well, it would be prudent to think of devices by means of which beneficent eentralization could be encouraged, perhaps by money.

\section{BRITISH ECONOMY}

Mr Stanley Baldwin helpod to win a place for himself in the history books by saying that wherever six economists were gathered together, there would be seven erudite opinions from which to choose. Without attributing to him one iota of clairvoyance more than he deserves, it is a fair guess that he would have been downcast to see how meagre was the harvest of economic innovation in the debate on the British economy on July 24. There was no shortage of economists, but nothing like a convincing remedy for what seems by common consent to be an unpleasant situation. In the circumstances, it is naturally tempting to wonder whether the traditional arguments about the economic condition of countries like the United Kingdom do not leave entirely out of account essential components of the problem. To say this is not to decry the economists or even to suggest that there is some mystical quality in the construction of an economic system which overrides the doctrines of Keynes and his successors. On the contrary, it is entirely possible that some simple economic stratagem might work like magic-a touch of devaluation, perhaps, or import controls. But which of the many possible remedies would it be best in practice to apply? Which diagnoses of the economic discontents which afflict the British economy are the most accurate? As the British economy is managed, it is uncommonly difficult to answer questions like these. The complaint that would have carned $\mathrm{Mr}$ Baldwin gratitude as well as renown is that the trouble with economists is that they have too fow tests for testing alternative theories. This is what lends a sense of unreality to debates like that in the House of Commons earlier this week. It is like being compelled to stake a fortune on the outcome of a horse race.

The way things are done in Britain, even diagnosis is difficult. Although the bare bones of the present economic troubles aro all too plain to see-too great a disparity between imports and exports, too great a labour force with no work to do, and too small a rate of economic growth-the fine details are surprisingly obscure. Why, for example, has the British economy been flying in the face of economic logic in recent months by sustaining a rapid growth of the import bill at a time at which credit is being restricted and industrial production held down precisely so as to achieve the opposite effect? What kinds of imports are they, anyway? And why are importers so attached to their potential imports that they go to all this trouble to surmount the several potential barriers which have been constructed to keep imports out? Just as people guess at remedies which might be applied, so they guess at reasons why things like this are happening. In reality, of course, it would be much safer to take steps to find out. No manufacturer of washing powder worth his salt would let his sales decline without seeking to discover in exhaustive detail just what is wrong with what he is trying to sell. By now, in any case, the necessary techniques of market research are quite well understood. In the circumstances, it is entirely anomalous that governments should be shy to do the same things in the complicated. and therefore treacherous fields in which they must operate. The most urgent need in the management of the British economy may well be the huge battery of social analysis which could help everybody to understand why this great formless system responds in the way it does to the pressures which afflict it constantly. It would be valuable, for example, to know just how and to what extent people's economic habits are affected by taxes, or by shortages of credit at the bank, or even-at times of economic wellbeing-to encouragements to spend.

In terms borrowed from the kinetic theory, this suggests that the management of the British oconomy would be a good deal easier if there were a microscopic as well as a macroscopic theory of how it functions. At the same time a better understanding of how the behaviour of the whole is determined by the behaviour of the parts of which it is composed would most probably suggest that the parameters which are supposed to characterize the working of the economic system may not be the most suitable or the most illuminating. As things are, it is easy onough to construct examples of how the fashionable statistics do not serve the purposes which are usually attributed to them. The numbers of people unemployed at any time may be, for example, a good measure of the inability of employers to keep unwanted men and women on their books, but they can only be the roughest measure of how efficiently the manpower of the country is deployed. The 17 per cent or so of the GNP being spent on industrial investment is low enough by comparison with what is spent in other countries comparable with Britain, but who is to answer the crucial question of how much of this investment will add to the real productive capacity of the country as a whole? It is just possible, of course, that these resources are being managed wisely, but it is unfortunately equally possible that they are being used merely to replace assets long since worn out. In this and a host of other ways, there are exceedingly fruitful problems which should be tackled by social scientists or people very much like them. 
In the long run, a more intimate involvement of social scientists in the foundations of the economy could serve not merely to reach more accurate decisions about the management of the economy but also to suggest a greater wealth of actions which might be taken. It may be something of a triumph that in the debate this week the Chancellor of the Exchequer was able to mention the word "devaluation" in public without pretending that all holders of sterling would turn their money into any other currency on offer, but this is only a modest relaxation. Why does he not also take up in public the arguments one way and the other for the maintenance of sterling as an international currency? And why does not his colleague, Mr Patrick Gordon Walker, take the edge off his fears that people on the margin between poverty and prosperity might be tempted not to work if welfare benefits were too generous by considering the potential advantages of a statutory minimum wage? Indeed, there is a good case for going even further and asking whether the British Government could not create the mobile labour force for which it is always crying out by making paymen $\mathrm{s}$ of actual money to people who change their jobs. Another possibility is that removal expenses might qualify tfor deduction of income tax, and there is of course a host of other possibilities all equally at odds with the conventions now followed. The difficulty in all this is that, in the absence of a detailed understanding of how the economy functions, the conventions are indispensable. They have become not safeguards but crutches.

\section{MORE COLLABORATORS}

Is all the present rash of international projects looking for members and finance, from Cern and its ambitions to build a $300 \mathrm{GeV}$ proton accelerator to the several offshoots of the international unions, it is important that EMBO should not be forgotten. (Given the name, indifference is a more real danger than forgetfulness.) Formally, the organization is now nearly four years old, and for much of that time it has leaned on the Volkswagen Foundation for support. Constitutionally it is a private company registered in Switzerland, and its aims are to foster research in molecular biology in whatever ways seem appropriate and potentially rewarding. There has been a small but imaginative programme of exchange visits between laboratories, and EMBO (which stands for European Molecular Biology Organization) reckons to have been able to act more quickly and informally in assisting research people to spend short periods in other laboratories than their own. But this is only a beginning. The organization is anxious quickly to increase its activities and to enlarge their scope. It would like to be able to finance-or at least to catalyse-long-term appointments; it wants to provide advanced courses, to be able to make research grants and finally to establish a laboratory of its own, with an independent source of funds. But ambitious plans like these are not easily accommodated within the framework of a private organization. Everybody seems to agree that funds would have to come from governments, and that governments would often be unable to hand over money unconditionally. Yet, as a meeting in Geneva some months ago (see Nature, 214,$445 ; 1967$ ) seems to have determined, this is not a serious stumbling block. Some kind of agreement between European governments and EMBO seems fortunately to be inevitable. The question remaining to be determined is what the agreement shall consist of.

The first thing to be said is that there was no accident in the choice of Geneva as a site for the first confrontation between the organizers and the governments which may eventually support them. (The Government of Israel has been helping for some time.) Obviously the example of Cern is intended as a model and, if it comes to that, Geneva would make a splendid site for the laboratory which EMBO would like to build. It is right to add, however, that EMBO's plans are comparatively modest. Not so long ago, the organizers had calculated that the cost of their ideal programme would come to hardly more than $£ 250,000$ a year-roughly three times its rate of spending now.

The laboratory is a bigger undertaking, costing perhaps $£ 2.5$ million to build and to equip, and something in excess of $£ 1$ million a year to operate. It is nosurprising that governments have been more syms pathetic towards the kind of work which EMBO hat been doing already, and sceptical about the laboratory and the delegation to EMBO of the duty to make grants for scientific research. The cost is not entirely negligible even when shared out among a dozen governments or more. But there are also fears, mostly unreasonable, that the creation of a centre of excellence on a European scale would simply serve to drain away from existing laboratories people who are scarce to begin with. The fallacy in this is that the laboratories like that which EMBO has in mind quite quickly increase the stock of people working in the field concerned. A more serious problem is that a central laboratory might take too many people away from teaching; some attention should be paid to this problem in the few months which remain before the next confrontation with the governments. On balance, it would make sense if the European governments-those which adhere to Cern and possibly some others as well-could agree to build the laboratory as well as to finance on a continuing basis the kind of work which EMBO has been doing so far.

Providing money for the financing of research projects on a European basis is a more tricky proposition, cheaper though it might well turn out to be. The trouble here, of course, is that a private organization must necessarily be less able than a government to make compromises between such conflicting pressures as the need to finance excellence and the need to help backwardness. In the long run, there would be great benefits in research councils operating on a continental scale, but nobody should be surprised if, for the time being, this particular dream is unfulfilled. 